\title{
Food and Health Science
}

\author{
E-ISSN 2149-0473
}

\author{
ORIGINAL ARTICLE/ORİJİNAL ÇALIŞMA
}

FULL PAPER

TAM MAKALE

\section{DEĞİŞİK İ̧̧LEME PROSELERİNİN BROİLERLERDE KULLANILAN LASALOSİT KALINTI DÜZEYLERİNE ETKİSí}

\author{
Namık BİLICİ \\ Karabük Üniversitesi, Sağlık Yüksek Okulu, Beslenme ve diyetetik Bölümü Balıklar Kayası Mevkii, Karabük, Türkiye
}

Received: 30.11 .2014

Accepted: 16.12 .2014

Published online: 20.12.2014

Kanatlı Koksidiyozisi eimeria türlerinin neden olduğu önemli bir protozon hastalığıdır. Kanatlı endüstrisinde önemli ekonomik kayıplara yol açmaktadır. Koksidiyozisin kontrölünde nikarbazin, halofuginon, robenidin, diklazuril, monensin, salinomisin, narasin, lasalosit ve maduramisin gibi ilaçlar kullanılmaktadır. Kullanılan ilaçların kalıntıları izlenmesi ve gerekli önlemlerin alınması insan sağlığı açısından büyük bir önem taş1maktadır. Bu çalışmada İstanbul'da tüketime sunulan tavuk eti ve yumurtalardan aldığımız 150'şer adet numune de lasalosit kalıntı ve düzey izlemesi yapılmıştır. Genel olarak broilerlerdeki (tavuk) yedirme koşullarında lasalosit 75-125 $\mu \mathrm{g} / \mathrm{g}$ ile sınırlandırılmıştır. $\mathrm{Bu}$ şartlarda yapılan yedirme denemeleri sonrasında 1. 3 . ve 5. ve 7. günlerde alınan dokularda analizler yapılmış, 1. 3. 5. gün dokularındaki lasalosit kalıntı düzeyi önemli bulunmuştur. Kalıntı miktarı yüksek olan 1. 3 . ve 5. gün dokuları kızartma, haşlama, $+4^{\circ} \mathrm{C}$ muhafaza ve dondurmaya işleme ve depolama proseslerine tabi tutulmuştur. Sonuç olarak lasalosit giderek hızla azalan bir rezidüye sahip olduğu ve dokudaki kalıntılarının 1sıl işlemlerden etkilendikleri tespit edilmiştir.

\section{Anahtar Kelimeler:}

Lasalosit, İyonofor antikoksidiyal ilaç, Kalıntı düzeyi, Isı1l işlem
Corresponding author:

Namık BíLİCI, Karabük Üniversitesi, Sağlık Yüksek Okulu, Beslenme ve diyetetik Bölümü Balıklar Kayası Mevkii, Karabük, Türkiye

E-mail: namikbilici@gmail.com

\begin{abstract}
:
Effect of the Lasalosit used in Broilers and Different Heat Treatment Process on its Residual Levels

Avian coccidiosis is an important disease caused by protozoa of the genus Eimeria. İt leads to significant economic losses in the poultry industry. For control of coccidiosis in avian, using pharmacological active substance such as nikarbazin, halofuginon, robenidin, diclazuril, monensin, salinomycin, naracin, lasalocit and maduramicin. Residues of used drugs are significant for human healthy. In this study, we have taken from the poultry meat and eggs available for consumption in Istanbul with 150 specimens were screened for lasalosit. In general, the optimal feeding conditions has been limited $75-125 \mu \mathrm{g} / \mathrm{g}$ for lasalosit. After the feeding under these circumstances $1 \mathrm{st}, 3 \mathrm{rd}$, 5th, and 7th day the tissues was analyzed. 1st, $3 \mathrm{rd}$, 5th days detected tissue residues were considered important. High residue including which 1 st, 3rd and 5 th day tissues treated fried, boiled, held on $+4^{\circ} \mathrm{C}$ and freezed. Consequently it was confirmed that lasolocid residue have decreasing and affected by heat treatment of residues in tissues.
\end{abstract}

\section{Keywords:}

Famagusta, coastal fishery, gillnet, trammel net, longline 


\section{Giriş}

Koksidiyozis birçok hayvan türünde çok ciddi sağlik problemleriyle seyreden ve kanatlı hayvanlarda ölümlere kadar varabilen protozoonlardan kaynaklanan bir hastalıktır. Kanatlılarda alimenter yollardaki bozunumlar ishalden kanlı ishale ardından da ölümlere hatta sürü ölümlerine yol açabilmektedir. Eimeria türleri tarafindan meydana getirilen, proventrikülden başlayarak kolona kadar olan emilim yollarının harabiyeti ve șiddetli ishalle karakterize olan bu hastalığın tedavi edilmediği takdirde ölümle sonuçlanması kaçınılmazdır. Tedavisinde değişik antibiyotiklerin yanı sira genelde antikoksidiyal olarak karboksilik iyonoforlar kullanılmaktadır (Parelman, 1993; Rokka, 2005).

Ulusal kalıntı kontrol planı 2007'de yapılan gruplandirmada antikoksidiyal iyonoforlar "B2b" grubunda değerlendirilmiş olup buna ilişkin laboratuvar alt yapısı, analiz yetkinliği ve referans olarak Pendik Veteriner Kontrol ve Araștırma Enstitüsü (PVKAE) gösterilmiștir. Lasalosit için kontrol limitini izleme; tespit seviyeleri için $10 \mu \mathrm{g} / \mathrm{kg}$, analizleri LC-MS ile doğrulama da LC-MS/MS ile $2 \mu \mathrm{g} / \mathrm{kg}$ düzeyleri olarak deklere edilmiştir (Bories, 2007; Resmi Gazete, 2007; GKGM, 2007).

Lasalosit özelliklerinden ve halk sağlığında direk kullanılmıyor olmasından ötürü Dünya Sağlik Örgütü (WHO) eksperlerince kritik önemde değerlendirilmiş dolayısıyla Office International des Epizooties (OIE) tarafindan Veteriner Hekimlik açısından koksidiyozun kontrolünde çok önemli bir antibiyotik olarak listelenmiştir (EFSA, 2007; EFSA, 2004; Bishop, 1996; Jordan,1990; Dubois, 2004).

Daha önce kanatlı dokularında ilaç kalıntı düzeylerinin ısı karşısındaki tepkisi Baydan ve ark. tarafindan 2001 yılında sülfadiazin yine aynı araştırmacılarca 2002 'de sülfadimetoksin, sülfakinoksalin ve sülfadoksin kalıntıları üzerine yapılmış olup farklı pişirme işlemlerinin sülfadimetoksin, sülfakinoksalin ve sülfadoksin üzerine önemli bir azalmaya neden olduğu bildirilmiştir (Baydan ve ark,.1998; Baydan ve ark., 2001). Pişirme ve dondurma işlemlerine ilişkin ise çok az sayıda çalışma olduğu görülmüş (Baydan ve ark., 2001), Dehai ve ark. (1996) kanatlı dokularında sülfadiazin kalıntılarının çeşitli pişirme, $-20 \mathrm{C}$ 'de dondurma ve bekletme ile azaldığını beldirmişlerdir (Dehai, et al., 1996).

Günümüzde LC-MS ile iyonofor antikoksidiyallerin 1ppb' nin altında bile tespitleri ve LC-MS/MS ile de doğrulamaları çok daha büyük duyarlılık oranlarında mümkün olmaktadır. Bu çalışma broilerlerde lasalositin kalıntı bırakma düzeylerinin belirlenmesi ve 1s1 stabilitesinin ortaya konmas1 amacıyla yapılmıştır.

\section{Materyal ve Metot}

Bu çalışma; İstanbul ilinden numune bazlı tarama testleri, yedirme sonrası doku ve karaciğer rezidüe seviyeleri ile yüksek düzeylerdeki kalıntının 1sıl işlemlere tepkisinin belirlenmesini içermektedir.

\section{Numune çalışması}

İki aşamalı olan çalışmamızın birinci evresinde İstanbul'un Anadolu ve Avrupa yakalarında 15 ilçesinden (Bahçelievler, Bağcılar, Bakırköy, Küçükçekmece, Gaziosmanpaşa, Fatih, Eminönü, Beyoğlu, Şişli, Güngören, Tuzla, Maltepe, Pendik, Kadıköy, Beykoz) topladığımız 150 adet yumurta ile 150 adet broiler eti örneği alınarak "Pendik Veteriner Kontrol Ve Araştırma Enstitüsü", (PVKAE) kalıntı laboratuarına etler soğuk zincirde, yumurtalar ise satış koşullarında en fazla 3 saat içerisinde taşındı. Numuneler alınırken yumurtalarda bir adet viyolden bir adet yumurta alınmasına, aynı firma aynı adres ve aynı parti malı olması durumunda ikinci bir numunenin alınmamasına özen gösterilmiştir (Tablo 1).

Piliç eti numuneleri alınırken de olabildiğince farklı parti, farklı kesim ve/veya firma olmasına dikkat edildi. Böylece yumurta ve piliç eti numunelerinin imkânlar dâhilinde farklı seçimi öngörülmüştür (Tablo 2). 
Tablo 1. Yumurta örneği alım tablosu

Table 1. Egg samples reception table

\begin{tabular}{|l|l|}
\hline Numune No: & $1-150$ adet yumurta \\
\hline Cinsi & Yumurta \\
\hline Ortalama ağırlı̆̆1 & 50-60gr/ad. yumurta \\
\hline Alındığı Yer & $\begin{array}{l}\text { B.Evler,Bağcılar,Bakırköy,K.çekmece,Gaziosmanpaşa,Fatih,Eminönü, } \\
\text { Beyoğlu,Şişli,Güngören,Tuzla, Maltepe,Pendik,Kadıköy,Beykoz, }\end{array}$ \\
\hline Özel İşareti & Yok \\
\hline Saklama koşulları & Normal satış reyonları \\
\hline Organolepsisi & Kendi yapı ve özelliklerinde, \\
\hline Satışa arz & Satışa arzedilmiş halde \\
\hline Düşünceler & Deformasyon, çatlak, kırık, delik olup olmadığı ve görünümü \\
\hline
\end{tabular}

*İlk- son kullanım süreleri tarihleri aralığ

Tablo:2. Piliç eti örneği alım tablosu

Table 2. Chicken meat sample table

\begin{tabular}{|l|l|}
\hline Numune No: & $1-150$ ad.arası numaralandırılmış Piliç eti numunesi \\
\hline Cinsi & Piliç eti \\
\hline Miktarı & Piliç eti: 230-350gr/ad. numune \\
\hline Hangi dokular & P.eti:deri+but+göğüs (yarım piliç) \\
\hline Alındığ1 Yer & $\begin{array}{l}\text { B.Evler,Bağcılar,Bakırköy,K.çekmece,Gaziosmanpaşa,Fatih,Eminönü,Beyo } \\
\text { ğlu,Şişli,Güngören,Tuzla, Maltepe,Pendik,Kadıköy,Beykoz, }\end{array}$ \\
\hline Özel İşareti & Yok \\
\hline Isıs1 & Piliç eti:-4, $+2^{\circ} \mathrm{C}$ \\
\hline Organolepsisi & Kendi yapı, kıvam, görünüş doku ve özelliklerinde \\
\hline Satışa arz & Satışa arzedilmiş halde \\
\hline Düşünceler & Halka satışa arz şeklinde reyon dolabından alınmasına dikkat edildi \\
\hline
\end{tabular}

Ekstraksiyon Yöntemi olarak PVKAE'nin de kullandığ 1 "Antikoksidiyal İlaç Kalıntılarını Tarama Analiz Talimatı" diye adlandırılan EFSA'nın ve AB referans laboratuarlarının da (Berlin) kullandığı aşağıdaki analiz yöntemi uygulanarak kalıntı düzeyleri belirlenmiştir.

Kullanılan Materyal, Standart ve Kimyasallar:

\section{Materyal:}

$200 \mathrm{~mL}$ ' lik cam beher ve $15 \mathrm{~mL}$ ' lik deney tüpü, 50 ve $75 \mathrm{~mL}$ 'lik silifli kaplı santrifüj tüpleri,

Vorteks karıştırıcı,

Ultrasonik su banyosu,

Soğutmalı santrifüj,
$\mathrm{N}$ (azot) evaporatörü,

Gold-Tandem MS/MS

Thermo Finnigan ${ }^{\circledR}$ MSQ LC-MS/MS sistem,

\section{Kimyasallar;}

1-Metanol, HPLC grade, $\left(\right.$ Merck $\left.^{\circledR}\right)$,

2-Asetonitril, HPLC grade, $\left(\right.$ Merck $\left.^{\circledR}\right)$,

3-Amonyum Asetat (J.T.Baker ${ }^{\mathbb{B}}$ )

4-NaOH, (J.T.Baker ${ }^{\circledR}$ )

5-n-Hekzan Reagend grade, $\left(\right.$ Riedel $\left.^{\circledR}\right)$

6-Toluen Reagend grade, $\left(\right.$ Merck $\left.^{\circledR}\right)$

7-Tetrahidrofuran, (Riedel de Haen ${ }^{\circledR}$ )

8-Formik asit, $\left(\right.$ Merck $^{\circledR}$ ) 


\section{Standartlar;}

İsim:

Açık Formül:

Kapalı Formül: $\quad \mathrm{C}_{34} \mathrm{H}_{53} \mathrm{NaO}_{8}$

Molekül Ăğırlığı: $\quad 612.77 \mathrm{~g} / \mathrm{mol}$

Erime Noktası: $\quad 180{ }^{\circ} \mathrm{C}$ (dec.) (lit.)

Saklama Koşulları: Standart madde $-20^{\circ} \mathrm{C}$ de saklanabilir.

Stabilite:

Stok çözeltiler metanolde hazırlanır ve $-20^{\circ} \mathrm{C}$ de muhafaza edilir. Çalışma çözeltileri $+4^{\circ} \mathrm{C}$ de 1 hafta stabil olarak saklanabilir.

Çözünürlük: $\quad$ Metanol de çözünür. Seyreltmeler metanol ile yapılabilir.

Tablo 3. Antikoksidiallerin Analizlerinde Cihaz Ayarları

Table 3. Device Settings in the anticoccidial Analysis

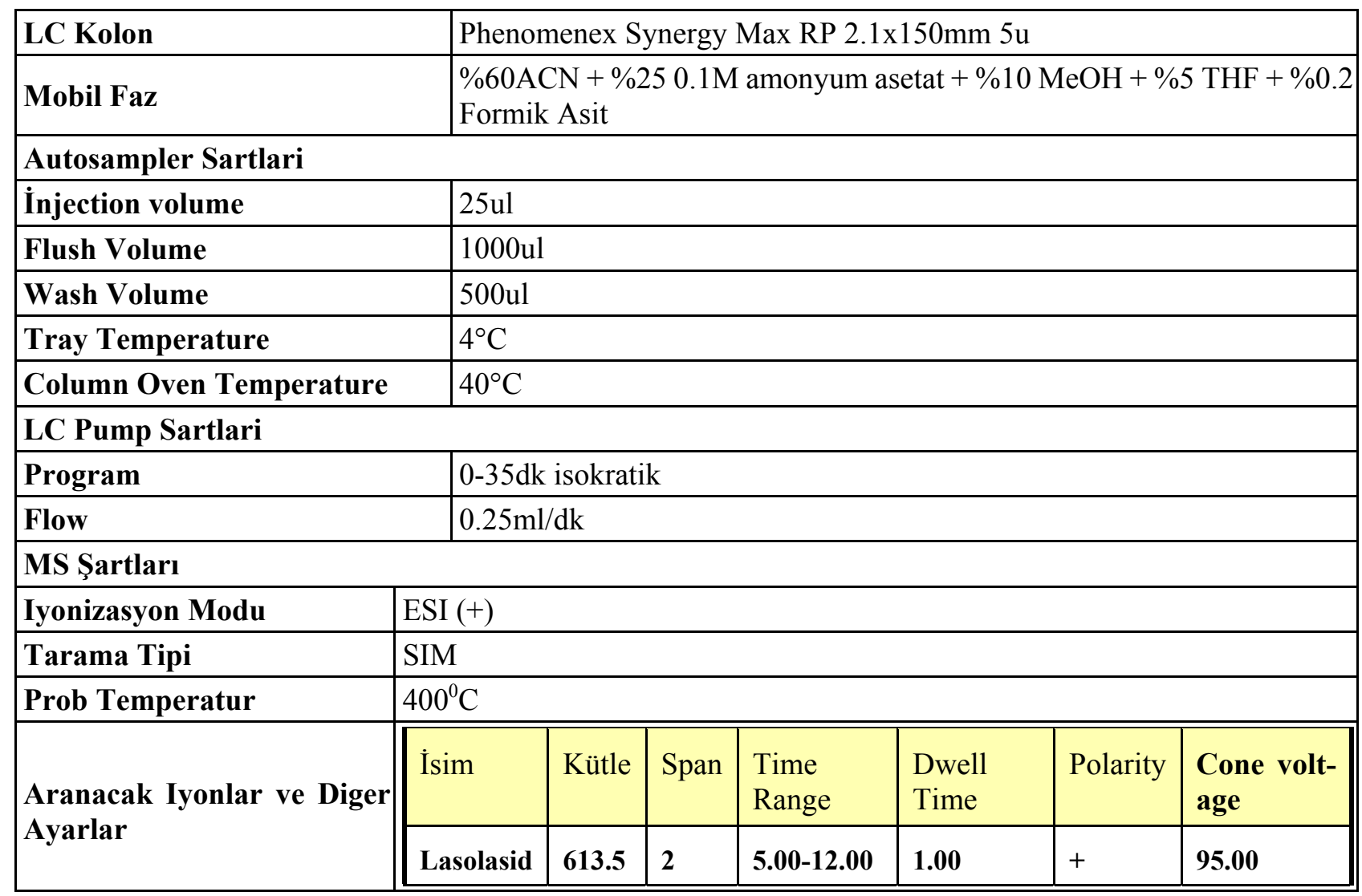




\section{Numunenin Hazırlanması}

Analizi yapılacak yumurtanın tamamı bir mikser ile broiler etinin 200g'ı homojenizatör yardımıyla iyice parçalanıp numune numuneler ayrılmış, herhangi bir bulaşmayı engellemek için tüm teçhizatın her işlem sonrası gerekli temizlikleri ileri düzeyde su, asetonitril, metanol ile yapılmıştır.

\section{Ekstraksiyon}

Elli veya $75 \mathrm{~mL}$ 'lik santrifüj tüpüne $10 \mathrm{~g}$ doku örneği, $15 \mathrm{~mL}$ asetonitril ve $2 \mathrm{~mL}$ saf su eklenerek 30sn vorteks karıștırıcı ile homojen hale getirildi. Homojenizatörde iyice parçalanan örneklerin olası parçacıkların yetersiz ayrışmasını önlemek amaciyla ortalama $10 \mathrm{dk}$ ultrasonik banyoda ileri düzeyde parçalanmaları sağlanmış, sonraki aşamada 1s1 ayarlanabilir bir santrifüj ile $4^{\circ} \mathrm{C}$ 'de 3000 rpm'de $10 \mathrm{dk}$ askudaki partiküllerin çökelmesi sağlanmıştır. Santrifüj sonrası üst fazdan 2,5 mL'lik kısmı 25mL'lik santrifüj tüpüne alınarak buna $4 \mathrm{~mL} 0,5 \mathrm{M} \mathrm{NaOH}$, ile $10 \mathrm{~mL}$ Hekzan: Toluen (1:1) çözeltileri ilave edilmiştir. Otuz saniye vortekste karıştırılıp 3000rpm'de 10dk santrifüj sonrası üst fazın tamamı ayrılarak $15 \mathrm{~mL}$ 'lik deney tüpüne örnekler alınmıştır. Üst fazın yumurtada en fazla ve doku kizartma numunelerinde en az olduğu gözlemlenmiştir. Kalan alt faza $5 \mathrm{~mL}$ Hekzan:Toluen (1:1) eklenerek santrifüj edilmiştir. Santrifüj sonrası üst faz ayrılarak birinci üst faz ile birleştirilmiş, elde edilen bu faz azot gazı altında $60^{\circ} \mathrm{C}$ 'de uçurularak elde edilen geri kazanım örnekleri $500 \mu 1$ asetonitril:su $(75: 25)$ ile insört viale alınarak LC-MS te analize alınmıştır.

Doğrulama testleri için yine yukarıdaki yöntem ile analitlerin tesbit limitleri kadar standart enjeksiyon yapılarak geri kazanım (recovery) ları test edilmiştir. Lasalositin kas dokusundan ayrıştırılması, sıv1-sıvı ekstraksiyonu ile analitlerin kirlilikten ayrıştırılması yapılarak LC-MS-MS sistemi ile doğrulaması aynı analiz peosedürleri içerisinde gerçekleştirilmiştir.

Analiz için Thermo Finnigan Surveyor LC pump, otomatik enjektör (Thermo Finnigan Surveyor Autosampler), LC kolon (Phenomenex Synergy Max RP 2,1x $150 \mathrm{mmx} 5 \mu$ ), $400^{\circ} \mathrm{C}$ Kolon Firın Isıs1, $25 \mu \mathrm{L}$ Enjeksiyon Hacmi, $0.3 \mathrm{~mL} / \mathrm{dk}$ Akış Hızı, 0-25dk Diagonal Akış programında ve \%60 asetonitril $+\% 250.1 \mathrm{M}$ Amonyum asetat $+\% 10$ Metanol $+\% 5$ Tetrahidrofuran $+\% 0,2$ Formik asit olan mobil faz şartları oluşturularak çalışma yapılmıştır.

\section{Besleme sonrası elde edilen doku örneklerinde ekstraksiyonu}

Çalışmanın ikinci evresi broyler temini, gruplandirma, yedirme, kesim ve ekstraksiyonundan oluşmuştur. Bursa'da ticari bir işletmeden alınan 150 adet Ross ırkı 16 günlük broyler pilici Bilecik ili İnhisar ilçesi Tarpak beldesine kafeslerde sorunsuz ve kayıp vermeden naklendilmiştir. Daha önceden hazırlanmış, ayrılmış, Lasalosit için " $L$ " 'kontrol için de ' $C$ ', yazılarak işaretlenmiş bölmelere yerleştirilerek besleme grupları oluşturulmuştur. Muhtemel aksaklıkların (ölüm, hastalık v.b.) tolere etmek amaçlı $\mathrm{L}$ ve $\mathrm{C}$ grubu dışında kalanlar ayrı bir bölmeye alınarak, beş gün boyunca kendi normal rasyonları, antikoksidiyal içermeyen rasyonları ile beslenme sürdürülmüş böylece eliminasyona neden olabilecek olas1 risklerden kaçınılmıştır.

Yem karışımı 20. günde Lasalosit için ton üzerinden hesaplama yapılarak lasalositin $90 \mu \mathrm{g} / \mathrm{g}$ miktarına denk gelen ilaç kısmı bir ön karışıma tabi tutulmuştur. Bu ön karışım ikinci bir karışımla homojen dağılımın sağlanacağından emin olunduktan sonra 100'er kg'lik pellet olmayan yemlere karıştırılmıştır. Bir sonraki gün (21.gün) yedirme sabahtan başlatılmış başlangıçtan itibaren kontrol grubunda belirgin olmakla birlikte tüm gruplarda yem alımında kesime kadar artarak devam etmiştir. Beşinci gün sonunda total yem tüketiminde artışa paralel olarak gözlemlenebilir ağırlık artış1 da gözlemlenmiştir. Beş günlük besleme sonrası kesimlere başlanmış (1., 3., 5. ve 7. kesim günleri) yapılarak analiz prosedürleri tüm gruplara aynen uygulanmıştır. gün boyunca konuya ilişkin değerlendirmeleri değiştirebilecek herhangi bir olumsuzluk meydana gelmemiştir.

Ekstraksiyon işlemi kontrol ve 1sıl işlem uygulanmış broiler örneklerinde dinlendirme işlemi sonrası (24 saat) başlatılmıştır.

Doku ve 1sıl işlem ekstraksiyonları bir arada ve uygun dinlendirme koşullarında 24 saat sonra başlatılmıştır. Ekstraksiyon için yöntem aynen korunurken doku ayrımına gidilmeden but ve gögüsten ortak alınan numuneler ile karaciğerden 10'ar gr'lık numuneler eş zamanlı ve paralel çalışılıp 3/4 parça da 1 sıl işlemler için ayrılmıştır. $\mathrm{Bu}$ 1sıl işlemlere saklanmış kısım göz kararı üç eşit parçaya bölünerek $-20^{\circ} \mathrm{C}$ 'de 10 gün tutulduktan sonra $-20^{\circ} \mathrm{C}$ 'den alınarak $0-+4{ }^{\circ} \mathrm{C}$ şartlarında $12-24$ saat çözündürülerek ekstraksiyona alınmıştır. İkinci parça toplumsal yemek kültürümüzden örneklenerek alışkanlıklarımıza paralel olarak fakat 
1S1 ve basınç ayarlanabilir bir kapta pişirmeye tabi tutulup pişmiş et ve et suyu ayrı, ayrı ekstrakte edilerek numaralandırılıp analizi yapılmıştır. Pişirme esnasında örnekle beraber pişirme kabına 250 gram doku için $50 \mathrm{ml}$ su ilave edilerek pişirme süresi 25 dakika ile sınırlandırılmıştır. Son 1/4parça ise yine beslenme alışkanlıklarımıza paralel olarak kızartılıp ekstraksiyonu yapılarak analize alınmıştır. Kızartma işlemi elektrikli kızartıcı kullanılarak ve tüketilebilir nitelikte kızarma kıvamına geldiğinde işleme son verilerek tamamlanıp, ekstraksiyona gidilmiştir. Hem pişirme hemde kızartma ișleminde tüketim alıșkanlıklarıyla birebir paralellik sağlanmasına azami riayet edilmiştir.

Ekstraksyion sonrası numunelerden elde edilen kısım organik bir çözücü yardımıyla SPE ve LLE teknikleriyle ile dokulardan ayrıştırılmıştır. İlaç kalıntılarını çözen organik bir solvent içinde var olan eluatlar azot gazı $\left(\mathrm{N}_{2}\right)$ altında kuruluğa kadar uçurulmuştur.

Örnek zenginleştirme olarak ifade edilen Sample Concentratör sistemiyle ekstraksiyon sonucu dokulardan ayrılarak organik çözücüye geçen ilaç kalıntıları cihaza verilinceye kadar vida kapaklı tüplerde $4{ }^{\circ} \mathrm{C}$ de muhafaza edilmiştir.

$\mathrm{Bu}$ çalışmanın deneysel kısmı çalışmaları için 31.10.2006-2006/175 tarih ve sayı numarası ile İstanbul Üniversitesi Veteriner Fakültesi Etik Kurulu Başkanlığı'ndan kurumundan 'Etik Kurul', izni alınmıștır.

\section{Bulgular ve Tartışma}

Kuzey İrlanda'da yumurtacı tavuklarda 6ay boyunca kullanılan lasalositin kalıntı miktarı olarak 1994 'te \%66 den 1995'te \%21'e inmesinin nedenlerinin başında granüler formun kullanımı gösterilmiş ve toz formun kullanımının azalması kalıntı olarak da bir azalmaya neden olmuştur. Buna karş1lk İngiltere'de lasalosit yumurta tavuklarında daha az tesbit edilmiştir. 1994 'te $\% 10.7$ ' sinde 40 $\mu \mathrm{g} / \mathrm{g}$ olarak yumurtada tesbit edilirken bu oran 1998 'de \%1.1 düzeyinde saptanmış fakat bu oran inandırıcı bulunamamıștır. Çünkü 2000 yılında $\% 33$ 'ünde ortalama $40 \mu \mathrm{g} / \mathrm{g}$ oranında taşıdığı tesbit edilmiștir. Yine Kuzey İrlanda'da TemmuzEkim 2001 tarihleri arasında yapılan başka bir çalışmada 148 adet yumurta numunesinden 3 adedinde $(\% 2)$ sadece $40 \mu \mathrm{g} / \mathrm{g}$ düzeyinde kalıntı taş1dığ 1 bulunmuş ve düşük düzeyde kirlenme ise 20 adette, $\% 13.5$ ' inde, 2 ile $27 \mu \mathrm{g} / \mathrm{g}$ olarak tespit edilmiştir. İngiltere'de bıldırcınlarda 20 kas doku ve 10 yumurta üzerinde yapılan bir çalışmada lasalosit rezidüsü 6 kas doku ve 10 yumurtada 120 ile $5400 \mu \mathrm{g} / \mathrm{g}$ arasında tespit edilmiştir (Jordan ve ark., 1990; Kennedy ve ark., 1998; Kennedy ve ark., 1996).

İsveçte 1999 yılında Rosen (2001) tarafından yapilan bir taramada 100 adet broiler karaciğerinin beşerli olarak bir araya getirilmesi yoluyla yapılan 20 örnek analizinde 11 örneğin narasinin kalıntıs1nın $0.04-0.67 \mu \mathrm{g} / \mathrm{g}$ arasında değiştiğini tespit etmişdir. Kuzey İrlanda'da yapılan bir başka çalışmada 40 adet yem rasyonundan \%22.5' inde monensinin prevantif dozun çok üstünde $5 \mathrm{mg} / \mathrm{kg}$ düzeyinde bulunduğu en yüksek buluna örneğin ise $44 \mathrm{mg} / \mathrm{kg}$ olduğu bildirilmiş sebepleri araştırıld1ğında ise yem fabrikalarındaki gerek normal gerekse pellet yapımı esnasında makine ve ekipmanların bulaşıklığı, personelin dikkatsizliğinin ana nedenler olduğu anlaşılmıştır (EFSA, 2004; Mc Evoy, 2002).

Yapılan piyasa araştırması İstanbul ilinden 15 ilçeden (Bahçelievler, Bağcılar, Bakırköy, Küçükçekmece, Gaziosmanpaşa, Fatih, Eminönü, Beyoğlu, Şişli, Güngören, Tuzla, Maltepe, Pendik, Kadıköy, Beykoz) değișik noktalardan numuneler alınmıştır. Yumurta ve doku numuneleri alınış şekil ve kriterleri olarak TGHB'nın numune alma formatı da göz önünde tutularak aşağıda tablolaştırılmıştır.

Yukarıda belirtilen yöntem ile PVKAE'de analize aldığımız 150 adet yumurtadan Lasalosit tespit edilebilir limitler dahilinde herhangi bir kalıntıya rastlanmamıștır. Yine broiler etinden mix olarak (deri + but + gögüs) hazırlanan karışımlardan da aynı yöntem ve tarama şartlarında negatif sonuç alınmıştır.

Broilerlerde antikoksidiyal ve zooteknik olarak da verim arttırıcı, yemden yararlanmayı yükseltici bir başka ifade ile yemin ete dönüşüm oranını pozitif yönde değiştirici olarak kullanılan Lasalosit için yedirme denemeleri süresince yem tüketiminde artış gözlemlenmiştir. $\mathrm{Bu}$; gözlem sonuçlarının kalitatif olması literatür olarak verilen ve amaç dışında olduğu için verilmemiş zooteknik ve parazitolojik araştırmalar ile paralel meydana gelmiştir (EFSA, 2004; Kennedy ve ark., 1996; Şanl1, ve ark.,1993; Mattabudul, 2002).

Kesimin 1., 3., 5., 7., günlerde yapılmas 1 hem ekstraksiyon periyodu hemde yapılagelen otoriter uygulamalarla paralellik arzetmesini sağlamıştır (EFSA, 2006, EMEA, 1999, EMEA, 2004). 
Negatif sıcaklık etkisi dışında diğer ısıl işlemler için bir bekletmeye gerek görülmemiştir. Ulusal mevzuatda antikoksidiyallerin B2b grubunda değerlendirilmesi $\mathrm{AB}$ laboratuarına atıfla PVKAE'nin antikoksidiyal kalıntı için temel referans alınmasını gerekli kılmıştır (Resmi Gazete, 2005; GTHB, 2007; Resmi Gazete, 2007; Elliot, 1998; McDouglas, et.al.,1998; Mortier et.al., 2005; Oehme et.al., 1998). Yöntemin ülkemizde ve $\mathrm{AB}$ 'de eş güdümlü kabul görmesi ve aynı ölçütlerin tekrarı, kontrol edilebilirliliği ve doğrulanabilirliliği açısından büyük önem taşımaktadır (Regulation EC, 2003).

Lasalosit için yapılan tespit düzeyi çalışmaları, recovery ve validasyon işlemleri sonrasında $1 \mathrm{ppb}$ düzeyinde kalıntı tespiti yapılabilidiği bunun da EFSA, EMEA ve ulusal verilerle paralel olduğu görülmüştür.

Lasalosit için yapılan tespit ve doğrulama çalışma sonuçları aşağıdaki gibidir;

Tablo 4. Lasalosit analiz ve doğrulama parametreleri

Table 4. Lasalosit analysis and validation parameters

\begin{tabular}{|l|c|c|c|c|}
\hline \multicolumn{5}{|l|}{ Lasalosit için tarama analiz parametreleri } \\
\hline İyonofor & $\begin{array}{c}\text { Tespit Limiti (ppb) } \\
\text { (LOD) }\end{array}$ & $\begin{array}{c}\text { Hesaplanabiliri Limit } \\
\text { (ppb) (LOQ) }\end{array}$ & Dedektör & Cone Voltajı \\
\hline Lasalosit & 2 & 4 & ESİ(+) & 90 \\
\hline Lasalosit için doğrulama analiz parametreleri \\
\hline Lasalosit & 1 & 2 & ESI $(+)$ & 30 \\
\hline
\end{tabular}

\section{Lasalosit LC-MS/MS Spektrumu:}

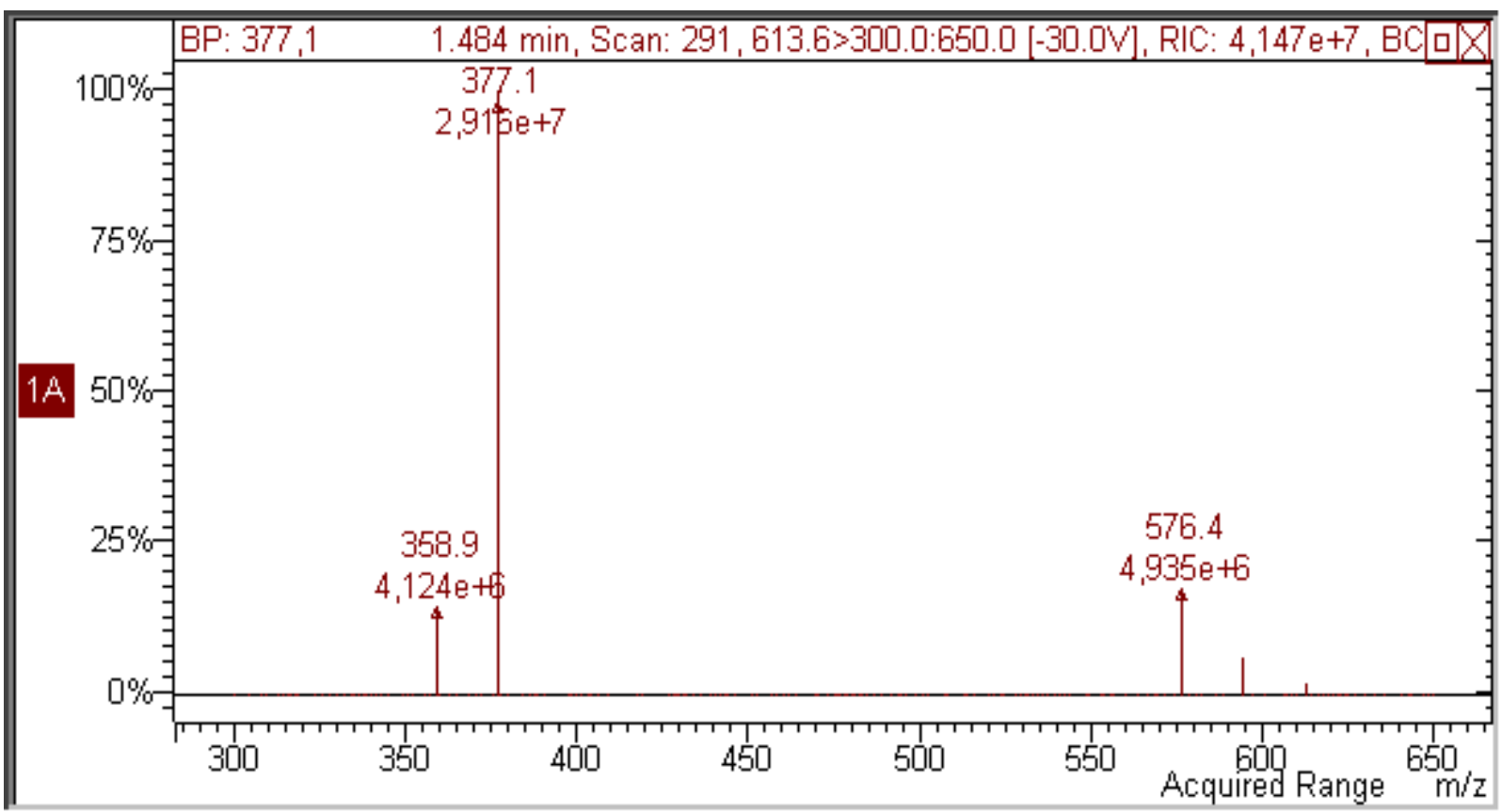

100ppb Mix Standart Kromotogramı: 
Journal abbreviation: J Food Health Sci

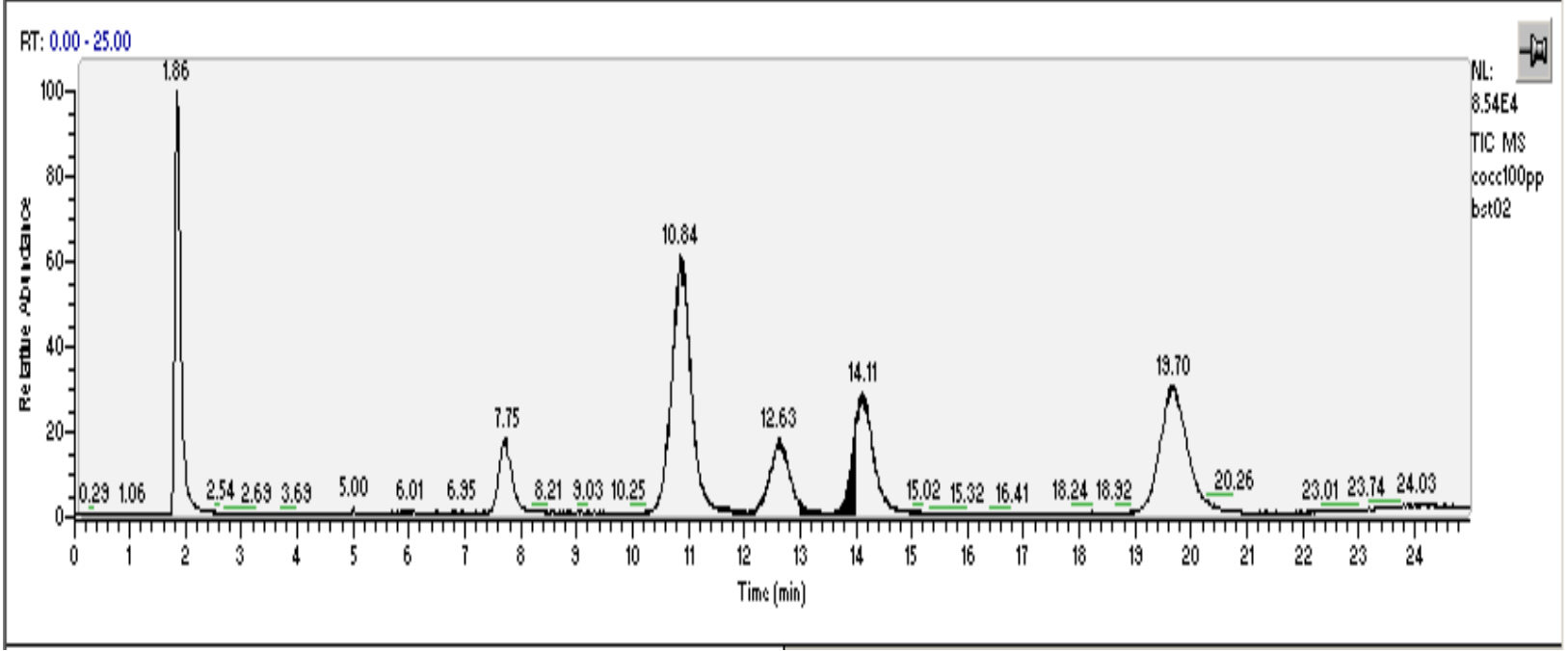

100ppb Mix Standart Kromotogramı:
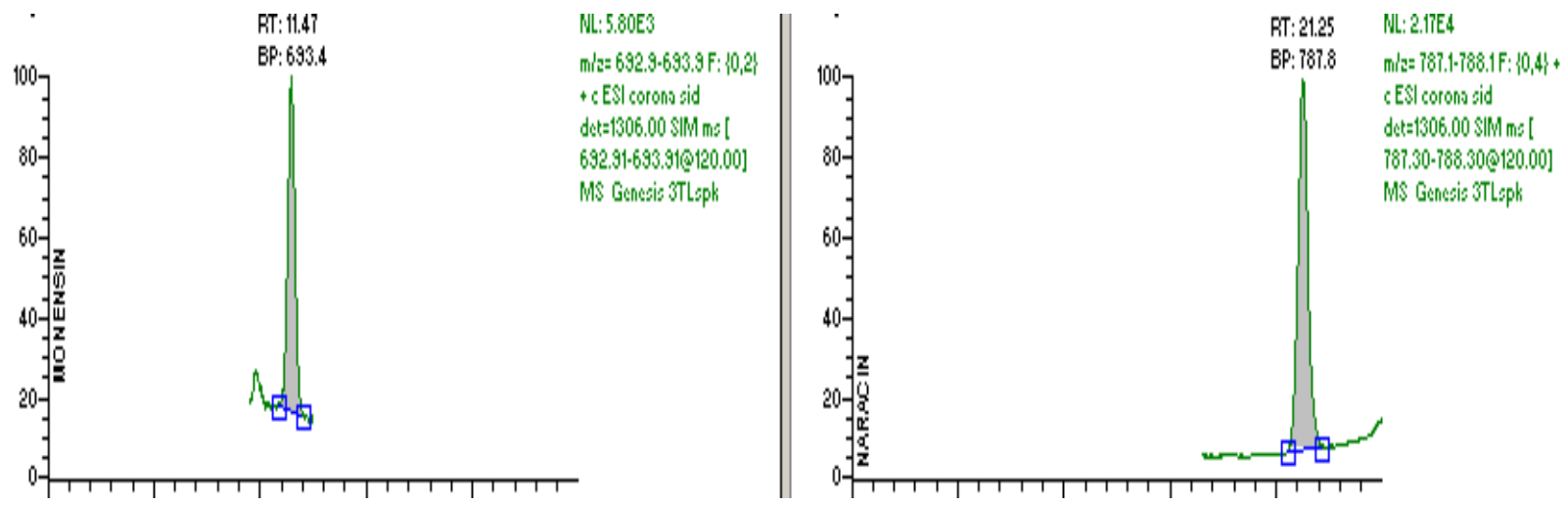

Spike yapılmış doku kromatogramı tespit limiti:

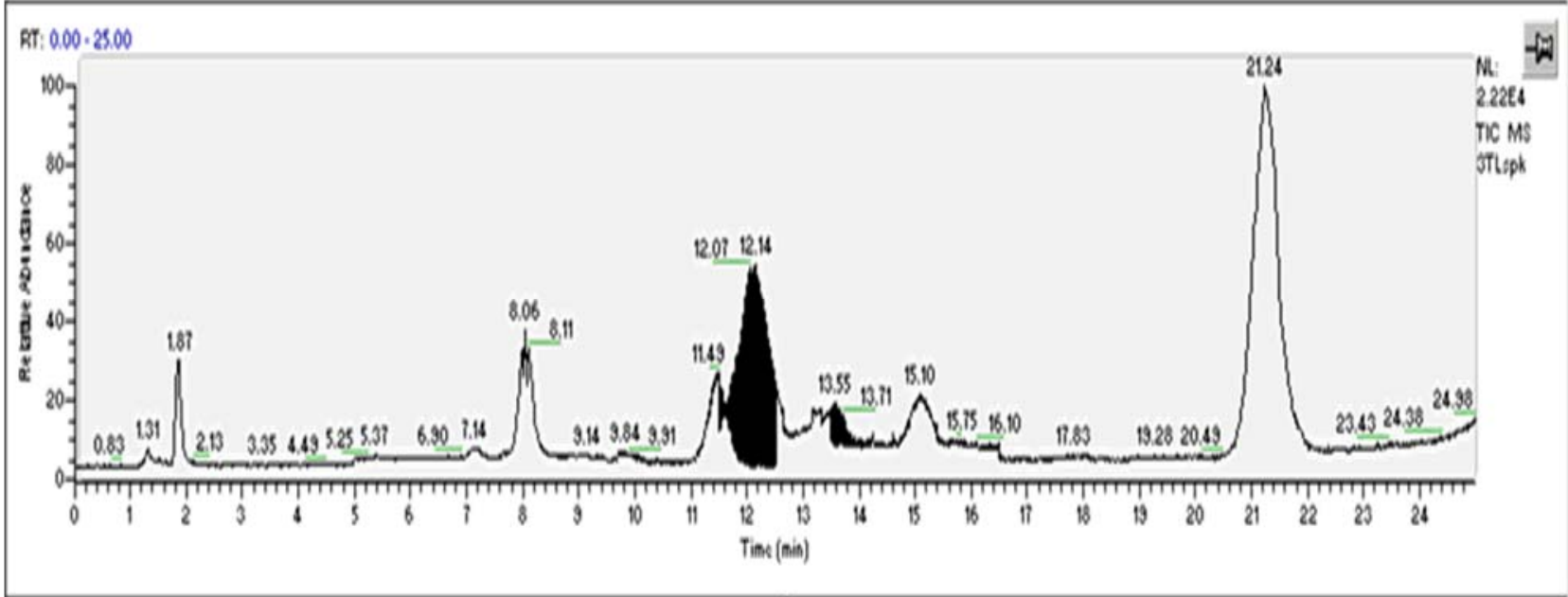


Lasalosit Kromatogramları:

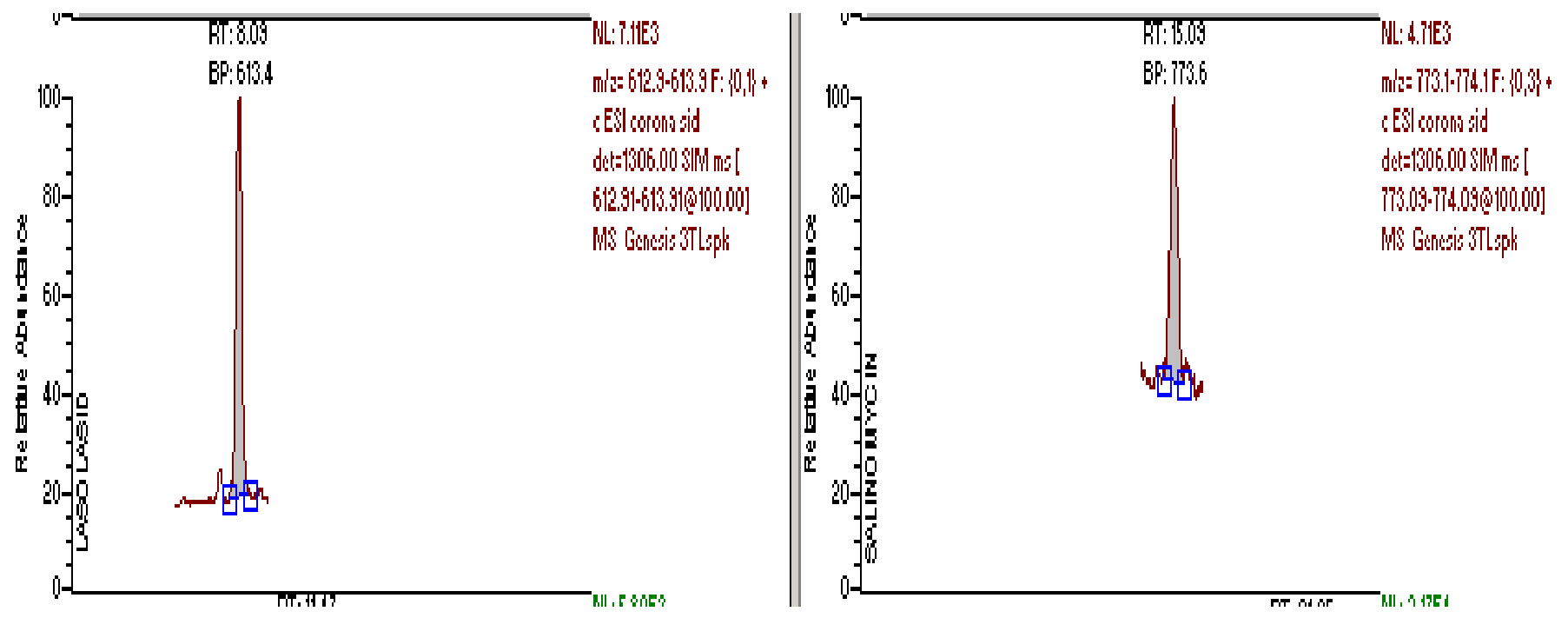

\section{Blank Doku Kromatogramı:}

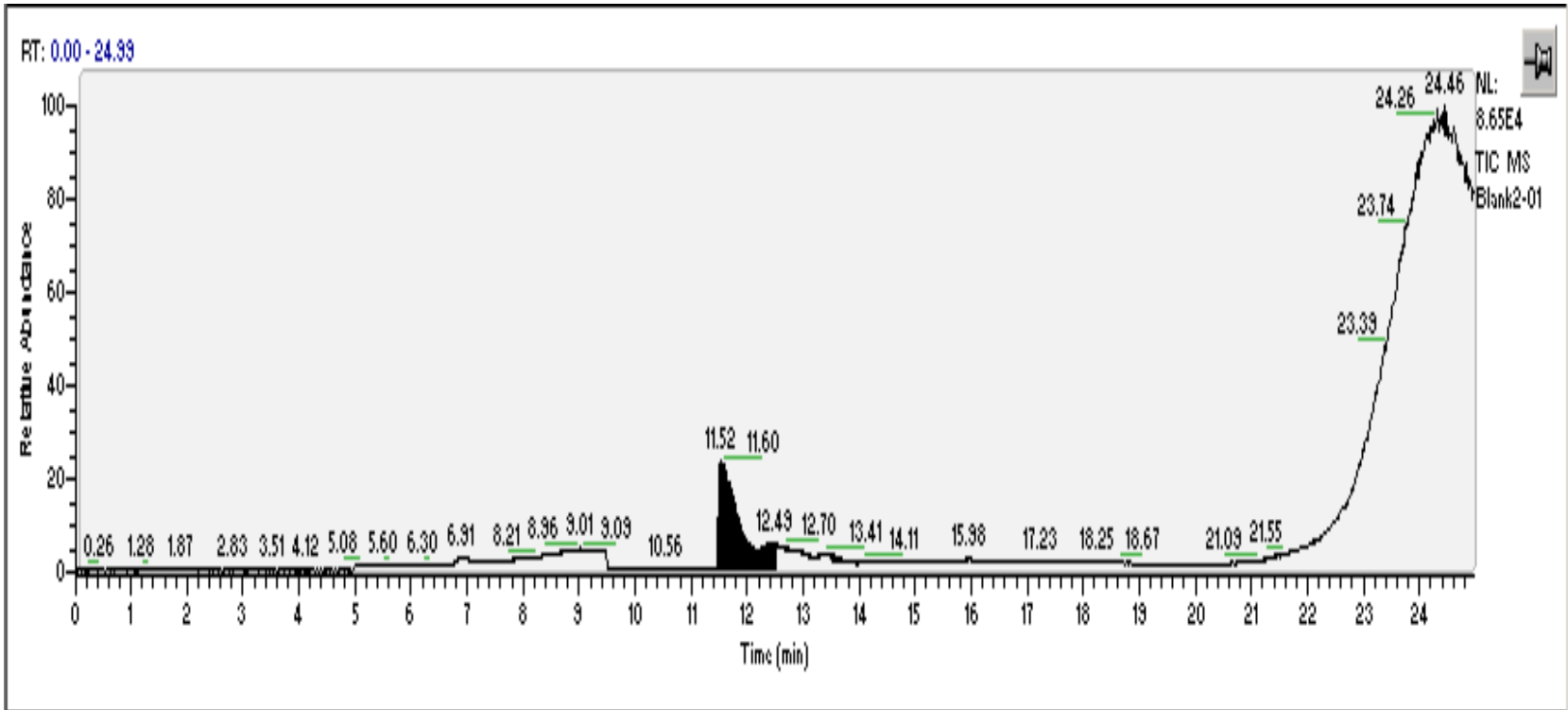




\section{Lasalosit Linearitesi:}

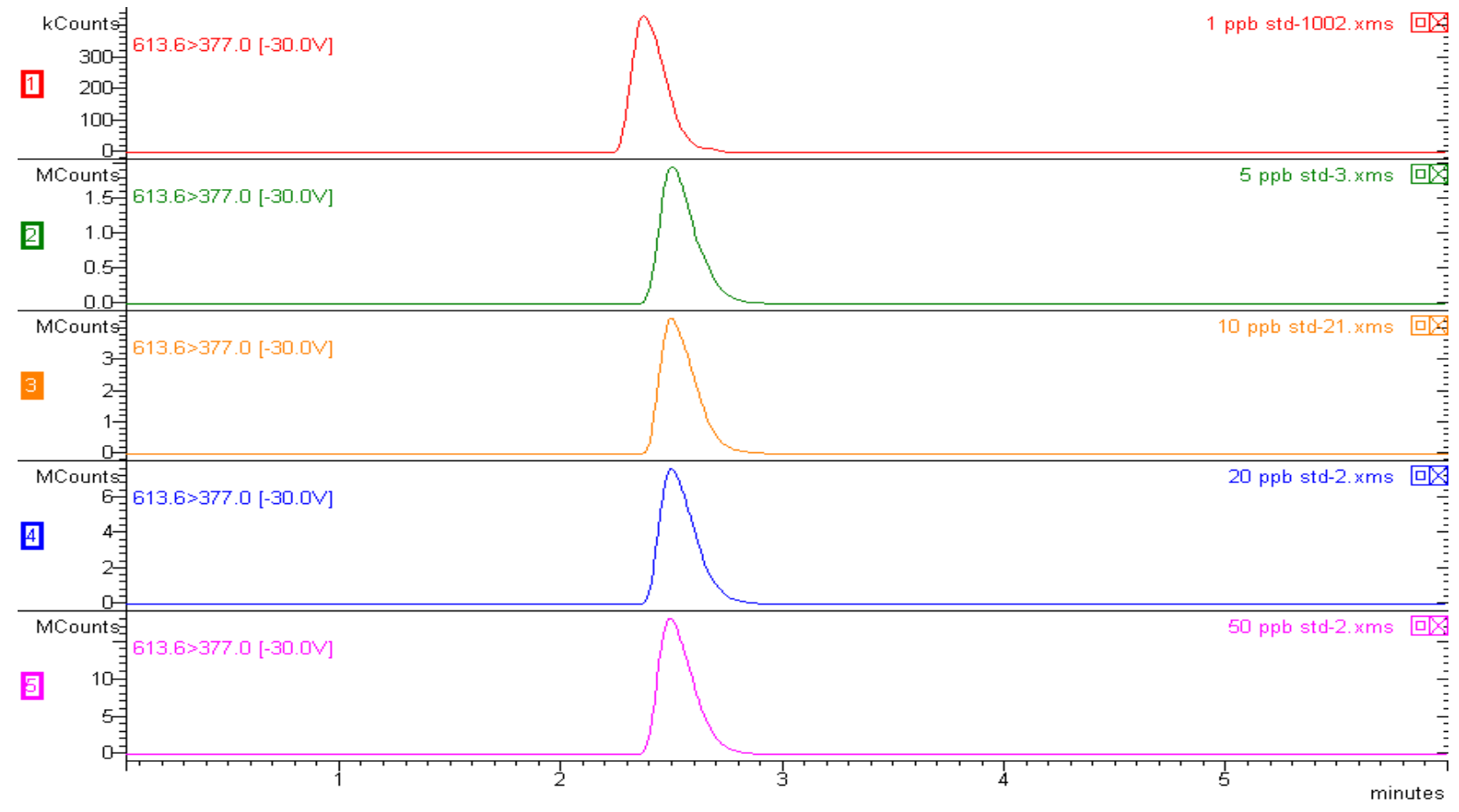

Spike Yapılmış Dokulardan Elde Edilen Lasalosit Kromatogramı:

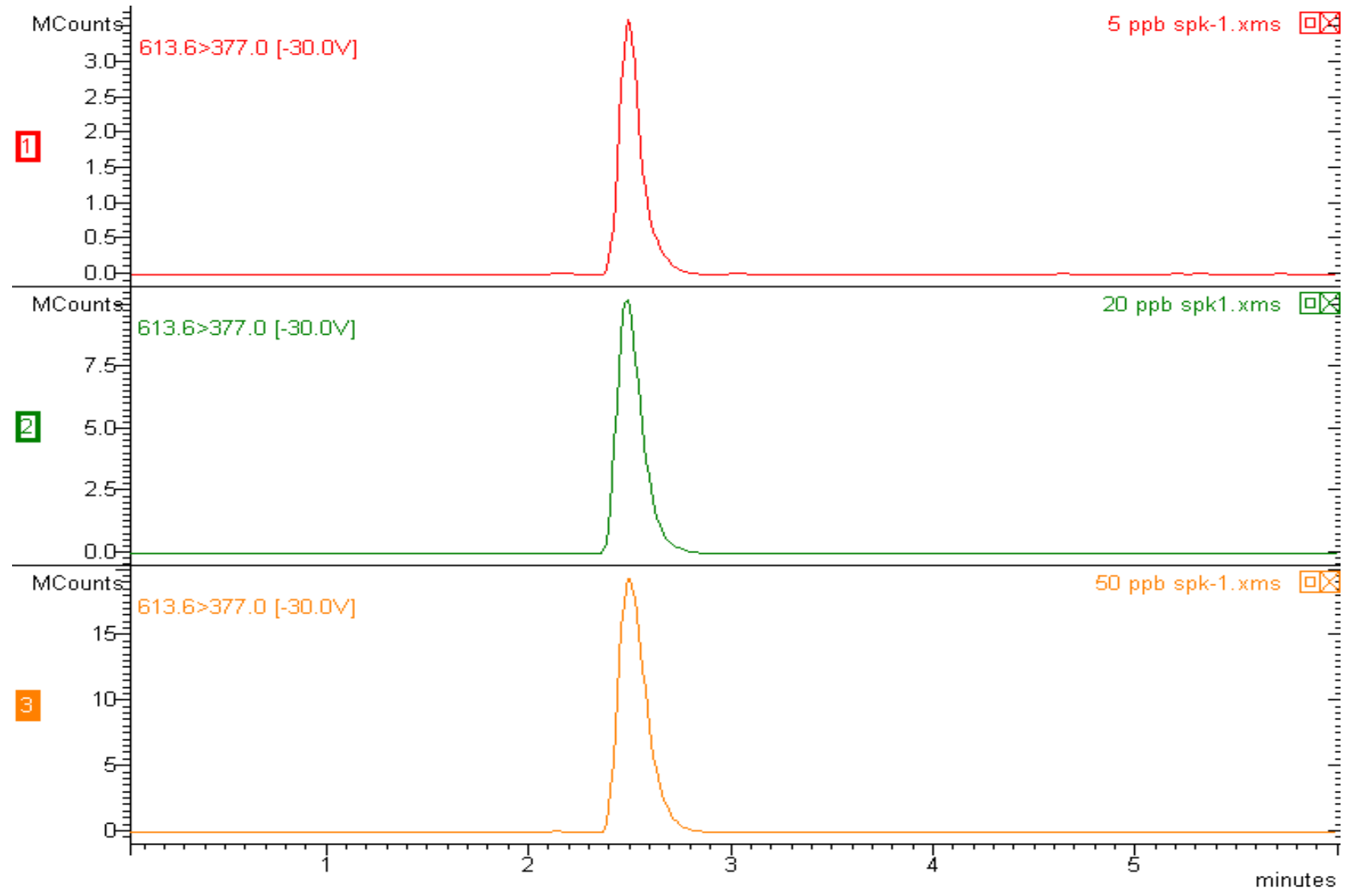




\section{Örnek Numune Kromatogramları:}

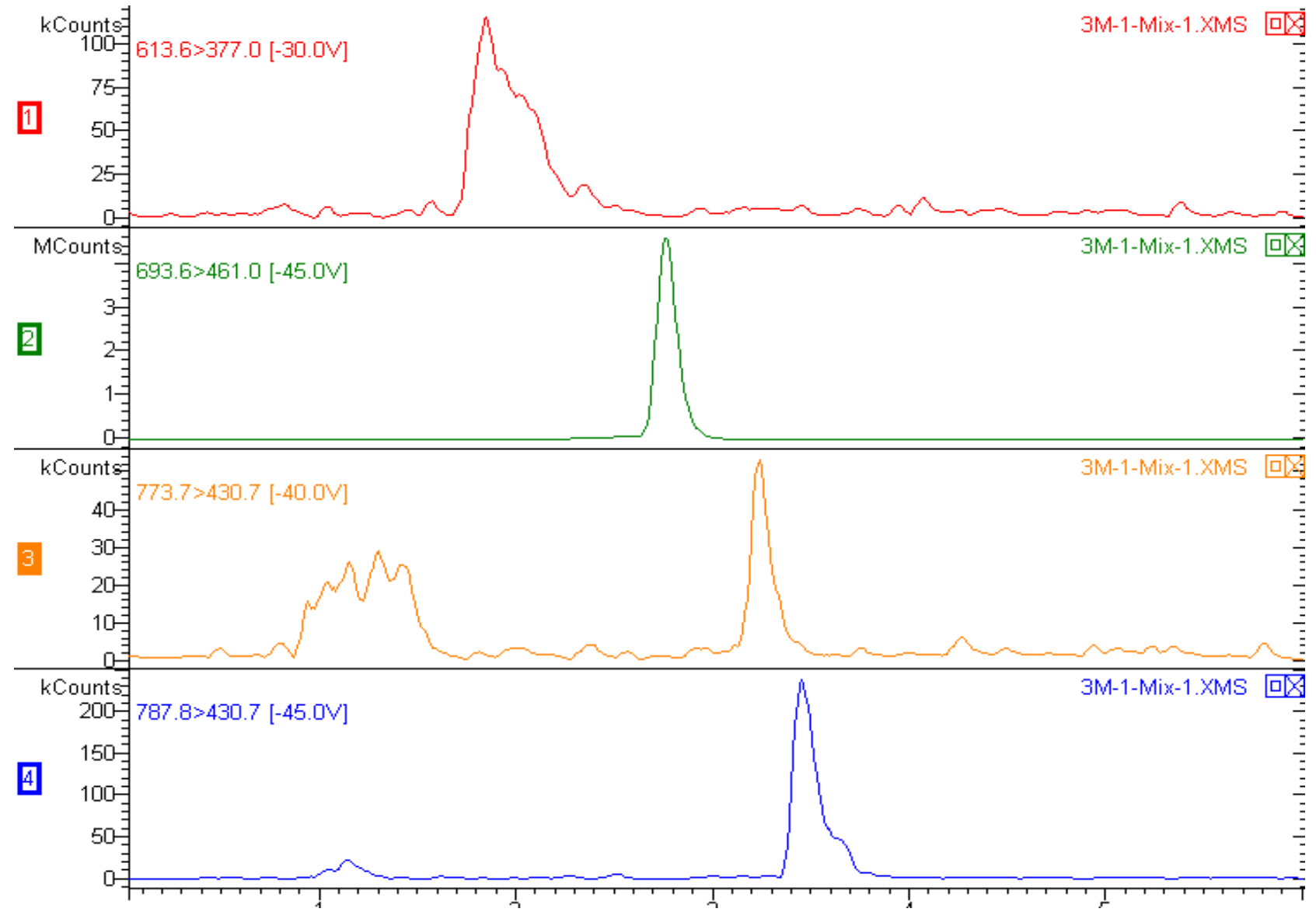

Standart enjeksiyonlardan sonra elde edilen geri kazanım lasalositte \%98, olmuştur. Bu yüksek değere ulaşılma nedeni lasalosit için çift değerli iyonları bağlama kapasitesi, kaybın daha az şekillenmesi ile makinaların yüksek performansta çalışabilmeleri ve yeni teknikler olmaları yanısıra özgün yapısının metotla iyi sonuç vermesine bağlanmıştır. Lasalosit için EMEA tarafindan MRL kas, deri+yağ, karaciğer, böbrek ve yumurtada sirasiyla $20,100,100,50,150 \mu \mathrm{g} / \mathrm{kg}$ olarak verilmiş ve ulusal mevzuatımızda da aynı oranlar aynı dokular için aynen alınmış ve kabul edilmiştir.

Ulusal otorite PVKAE'nin yapacağı izlemeyi LCMS ile doğrulamayı ise LC-MS-MS ile tesbit seviyesini $10 \mu \mathrm{g} / \mathrm{kg}$ ve doğrulama seviyesini ise 2 $\mu \mathrm{g} / \mathrm{kg}$ ile yasal olarak düzenlemiş ve karar limiti olarak Lasalosit için $>20 \mu \mathrm{g} / \mathrm{kg}$ olmasını kararlaştırmıştır (Resmi Gazete, 2007, GTHB,2007). Bu ulusal ve AB yasal mevzuatının yanısıra kullanımı devam edegelen Lasalosit' in de dahil olduğu karboksilik iyonoforlar için kullanım parametreleri hususunda ülkemizde herhangi farklı bir saha taramasina rastlanmamıştır. $\mathrm{Bu}$ sayılanların ışığında lasalositin de içinde bulunduğu karboksilik iyonoforların mevcut kullanımları, yapıları, direnç oluşturma periyotlarının uzunluğu, koksidi etkenlerine etkin ve özgün etkimelerinden ötürü kullanımlarının devam edeceği kanaati bir çok literatürce de desteklenmektedir (Ebrahimezhad, 2005; Rokka ve Peltonen., 2006; Elliot, ve ark., 1998). Lasalosit için yapılan LC-MS tespit ve LCMS/MS doğrulama analizleri sonucunda alınan örneklerden bir kaçı aşağıda verilmiştir. Verilen analiz raporları günlere bölünerek ortalama ideal olan, aynı grup örnekleri temsil edebilen, anlizlerden sadece birer adedi konulmuştur. $\mathrm{Bu}$ örnek analizler 1., 3., 5. ve 7. günlerden birer adet olmak üzere alınarak karboksilik iyonoforun düzeyi, günlere göre azalma durumu ve düşüş trendi hakkında bilgi vermesi açısından son derece 
çarpıc1 oldukları değerlendirilmiştir. Burada Lasalosit' in yüksek seviyelerde bulunabilme eğiliminde olduğu tespit edilmiştir. Analiz örnekleri 7. günü raporları tespit ve doğrulama limitlerimizin çok altında bulunmuştur.

Lasalosit broiler mix dokusunda 1-7. günler arasında bulunan kalıntı değerleri aşağıda verilmiştir.

Yapılan kesimlerin 1., 3. ve 5. günlerinde kalıntı miktarın inen doğrusal bir eğim göstermesi, aradaki farklılıkların yüksek oluşu, Kinetiğinin; ilk geçiș etkisi ile büyük oranda atılımını sağladığı, kalan miktarın ise yapılmış çalışmalara paralel olarak metabolizmada hizla degrade edildiği şeklinde yorumlanmıştır. 7. günde lasalosit için herhangi bir kalıntıya rastlanmazken 5. gün verileri $\mathrm{AB}$ otoritesine paralel olmuştur. Yapılan 1sıl işlemlerde sırasıyla kızartma, kaynatma ve dondurmada 1 sıl her işlemde lasalositin yıkımlandığı görülmüştür. Y1kımlanma lasalositte daha orantılı bir düşüş kaydetmiştir. Lasalositin atılım bakımından doku konsantrasyonunun daha geç degradasyonu, 1sıl işlemlerden de kaynatmanın lasalositi daha az yıkımladığı aşağıda verilen grafiklerden de anlaşılacağı üzere lasalositin daha istikrarlı olma eğilimine sahip olduğuna tanık olunmuştur.

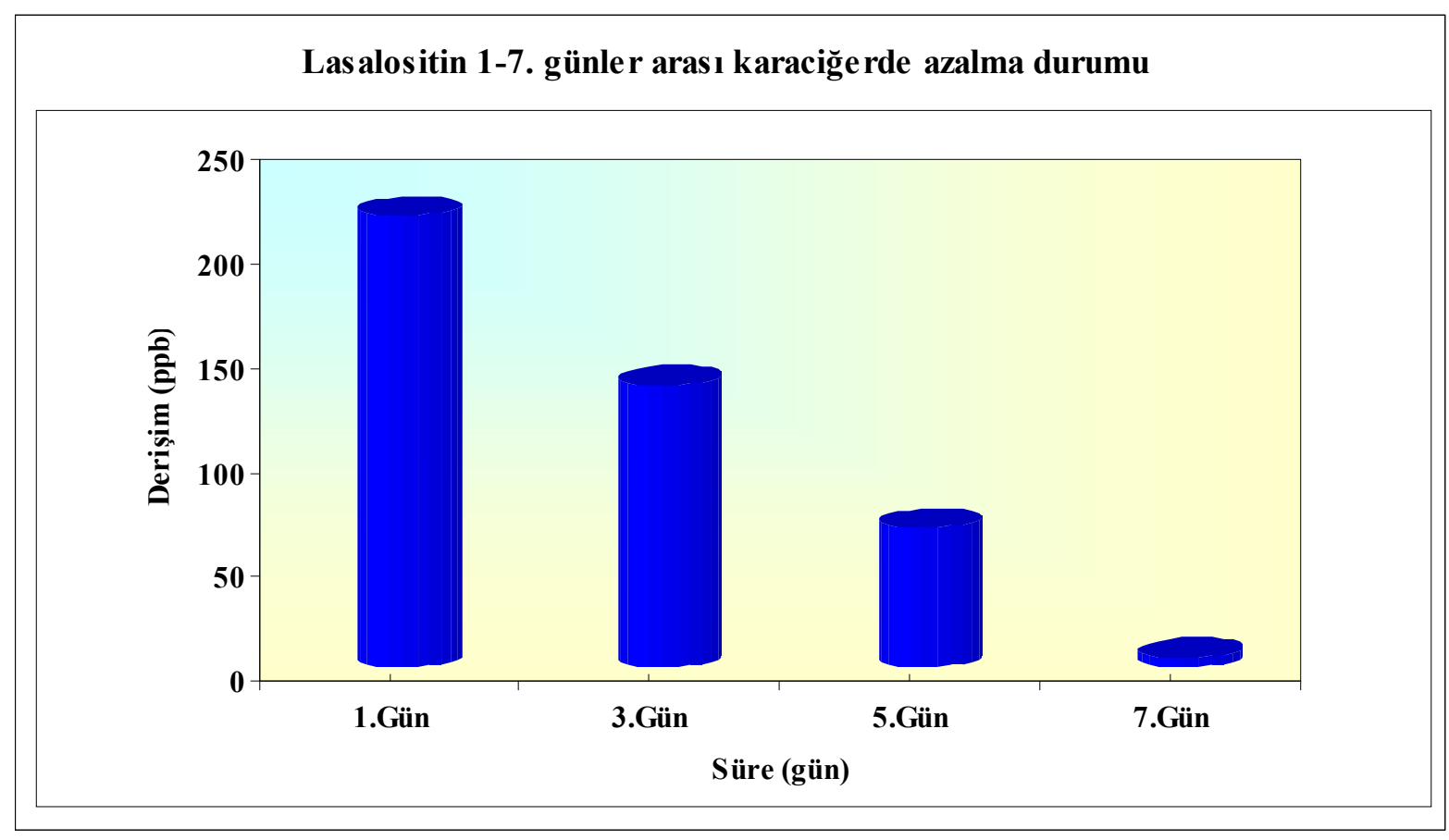

Şekil 1. Karaciğerde lasalositin zamana bağlı değişim konsantrasyonu

Figure 1. Lasalosit time-dependent concentration change in the liver 


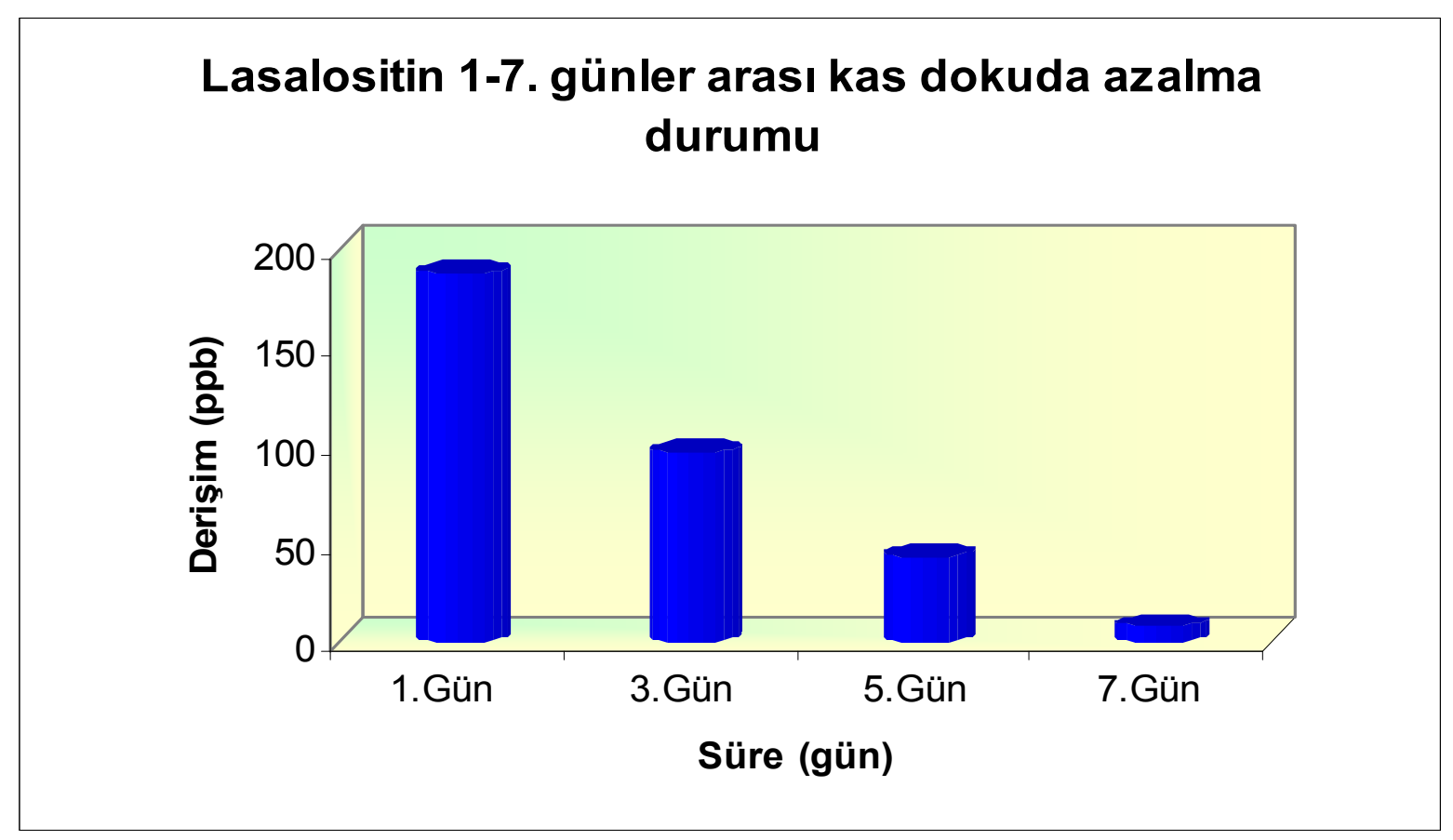

Şekil 2. Dokuda lasalositin zamana bağlı değişim konsantrasyonu

Şekil 2. Lasalosit time-dependent change in tissue concentration

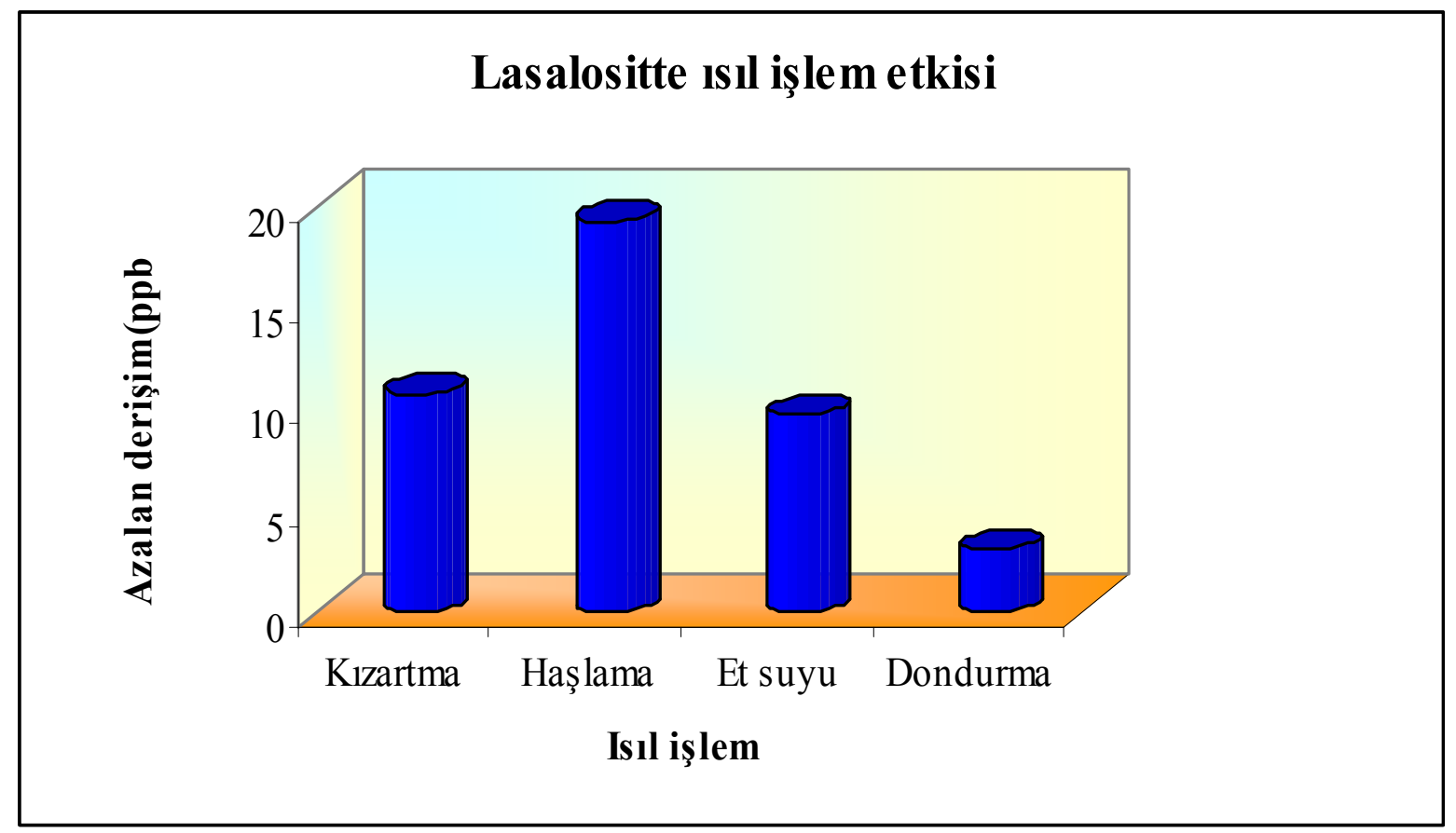

Şekil 3. Isıl (kızartma, haşlama ve dondurma) işlemlerin Lasalosit kalıntı düzeyleri üzerine etkisi

Şekil 3. The effect of heat treatment on Lasalosit residue levels (fried,boiled and frozen) 
Lasalosit içeren doku üzerine 1 șl işlem uygulanması şeklinde şu ana kadar her hangi bir literatüre rastlamamamıza karşın bir başka iyonofor olan narasin üzerine yapılan çalışma ile başkaca sülfadimetoksin, sülfakinoksalin, sülfadoksin ve sülfadiazin üzerine yapılan çalışmalarla da uyumlu olduğu, hassasiyet, tesbit limiti, özgünlük bakımından gözlem ve verilerin çok daha anlamlı olduğu görülmüştür (Baydan et.al., 1998, Dehai et.al. 1996, ,Rokka et.al., 2005).

İyonofor antikoksidiyallerden lasalosit içeren doku üzerinde 1 sıl işlem uygulayarak 1s1 karşısındaki davranışlarına ilişkin benzer bir çalışmada Rokka'nın bir başka iyonofor olan narasin üzerinde yapmış olduğu çalışmaya paralellik arzetmiştir. Buna karşılık doku degradasyonuna ilişkin sonuçlar hem moleküllerin farklılığı hemde analiz metodunun farklılığına bağlı olarak değişim göstermiştir. Metod farklılığı ile beraber benzer sonuçlar 1 sıl işlemlerin iyonoforları belli düzeylerde yıkımladığı ve termo-labil olan iyonoforların etkilenmelerinin düşük 1sıdan ziyade yüksek 1sıda daha fazla olduğu müşahade edilmiştir.

Tablo 5. Lasalosit spike edilen dokuların kızartma, haşlama ve dondurma sonrası doku kalıntı miktarlar1

Table 5. Lasalocid spiked tissue residue levels (fried, boiled, frozen)

\begin{tabular}{|c|c|c|c|c|}
\hline \multicolumn{5}{|c|}{ Lasalosit spike edilen dokularda kızartma sonrası düzeyler } \\
\hline No & \multicolumn{2}{|l|}{ Konsantrasyon $(\mu \mathrm{g} / \mathrm{kg})$} & \multicolumn{2}{|c|}{ Tespit $(\mu \mathrm{g} / \mathrm{kg})$} \\
\hline 1 & \multicolumn{2}{|l|}{100} & \multicolumn{2}{|c|}{73,487} \\
\hline 2 & \multicolumn{2}{|l|}{100} & \multicolumn{2}{|l|}{106,89} \\
\hline 3 & \multicolumn{2}{|l|}{100} & \multicolumn{2}{|l|}{89,798} \\
\hline 4 & \multicolumn{2}{|l|}{100} & \multicolumn{2}{|l|}{86,696} \\
\hline 5 & \multicolumn{2}{|l|}{100} & \multicolumn{2}{|l|}{81,752} \\
\hline 6 & \multicolumn{2}{|l|}{100} & \multicolumn{2}{|l|}{78,663} \\
\hline 7 & \multicolumn{2}{|l|}{100} & \multicolumn{2}{|l|}{90,504} \\
\hline 8 & \multicolumn{2}{|l|}{100} & \multicolumn{2}{|l|}{93,251} \\
\hline 9 & \multicolumn{2}{|l|}{100} & \multicolumn{2}{|l|}{83,545} \\
\hline 10 & \multicolumn{2}{|l|}{100} & \multicolumn{2}{|l|}{90,41} \\
\hline & \multicolumn{2}{|l|}{ Ort. $\%$} & \multicolumn{2}{|l|}{87,4996} \\
\hline & \multicolumn{2}{|l|}{ Ort. \% } & \multicolumn{2}{|l|}{87,5} \\
\hline & \multicolumn{2}{|l|}{ Recovery \% } & \multicolumn{2}{|l|}{98} \\
\hline & Reel kzt. Doku mikt. & & 89,2857 & \\
\hline & Kayıр & & 10,7143 & \\
\hline & Lasalosit spike & sonrası $\mathbf{k}$ & alıntı düz & yleri \\
\hline No. & Konsantrasyon $(\mu \mathrm{g} / \mathrm{kg})$ & $\begin{array}{l}\begin{array}{l}\text { Tespit } \\
(\mu \mathrm{g} / \mathrm{kg})\end{array} \\
\end{array}$ & & \begin{tabular}{|l}
$\begin{array}{l}\text { Et suyu } \\
(\mu \mathrm{g} / \mathrm{kg})\end{array}$ \\
\end{tabular} \\
\hline 1 & 100 & 85,42 & & 8,456 \\
\hline 2 & 100 & 73,25 & & 12,083 \\
\hline 3 & 100 & 77,7 & & 9,592 \\
\hline 4 & 100 & 79,87 & & 8,884 \\
\hline 5 & 100 & 81,04 & & 8,065 \\
\hline 6 & 100 & 78,66 & & 10,24 \\
\hline 7 & 100 & 80,69 & & 9,298 \\
\hline 8 & 100 & 81,36 & & 7,063 \\
\hline 9 & 100 & 77,25 & & 11,107 \\
\hline 10 & 100 & 76,42 & & 10,255 \\
\hline & Ort. & 79,166 & & 9,5043 \\
\hline & Reel ort. Doku & 80,78163 & & 9,698265 \\
\hline & Ort. Haşl. Et \% & 80,78 & & Et suyu $\% 9,7$ \\
\hline & Recovery \% & 98 & & \\
\hline & Reel hasl. Et dokuda kayıp & 19,22 & & \\
\hline & Et suyuna geçen \% & 9,7 & & \\
\hline
\end{tabular}




\begin{tabular}{|c|c|c|c|}
\hline Table & Devamı & & \\
\hline & Lasalosit spike dokuların -2 & izeyleri & \\
\hline No & Konsantrasyon $(\mu \mathrm{g} / \mathrm{kg})$ & Tespit( $\mu \mathrm{g} / \mathrm{kg})$ & \\
\hline 1 & 100 & 95.212 & \\
\hline 2 & 100 & 99.812 & \\
\hline 3 & 100 & 93.693 & \\
\hline 4 & 100 & 93.628 & \\
\hline 5 & 100 & 92.928 & \\
\hline 6 & 100 & 96.780 & \\
\hline 7 & 100 & 97.743 & \\
\hline 8 & 100 & 94.155 & \\
\hline 9 & 100 & 87.644 & \\
\hline 10 & 100 & 98.988 & \\
\hline & Ortalama \% & 95.058 & \\
\hline & Ort. \% & 95 & \\
\hline & Recovery \% & 98 & \\
\hline & Reel değer \% & 96,93877551 & 96,94 \\
\hline & Reel kayıр \% & \begin{tabular}{|l|}
3,06122449 \\
\end{tabular} & 3,06 \\
\hline & Ortalama & & $5.0 \%$ \\
\hline & Dondurma testinde kayıp \% & & $3.06 \%$ \\
\hline & Normal dokularda Recovery: \% & & $98.0 \%$ \\
\hline
\end{tabular}

Kayıp oranının lasalosit için kızartmada, kaynatma ette, $-20^{\circ} \mathrm{C}$ 'de dondurmada sirasiyla 10.71, 19.26, 3.06 ppb miktarlarında olduğu görülmüştür. $\mathrm{Bu}$ veriler ile şu ana kadar karboksilik iyonoforlardan lasalositin 1sıl işlem karşısındaki tepkisinin miktar ve oranı ilk defa net ve ölçütlü ortaya konulmuştur. K1zartma işleminde dokudaki su kaybından dolayı ağırlık azalmasına bağlı olarak rezidüel değerin yüksek çıkması değerlendirme esnasında doku üzerinden işlem yapılarak olası bir karışıklığa neden olunmadığı gibi amacımız olan sosyal yemek kültürü şeklinde işleme esnasındaki kayıplar hedeflendiğinden amaç dışına da çıkılmamıştır.

\section{Sonuç}

Besleyici değeri, ucuz maliyeti ve yüksek tüketimi göz önüne alındığında broiler etlerinde önemli bir risk faktörü olan Lasalosit kalıntılarının izlenmesinin büyük önem taşıdığı ve Lasalosit kalıntısının 1sıl işlemlere son derece hassas olduğu görülmüştür. AB otoritelerince yürütülen kalıntı aktivite araştırmalarının karar noktalarının farklı bağımsız ve ciddi anlamda belirleyici araştırmalar sonucu ortaya konulduğu bilinmektedir. Yapılan bu çalışmada elde edilen değerler itibariyle tutarlilik ve hassasiyet olarak daha iyi sonuçlara ulaşılmış olunmasının önemli bir gelişme olduğu düşünülmekte dahası bu durumun üzerinde çalışılan ana- litik cihazların yeni ve yüksek hassasiyet değerlerine ulaşabilmesi, stabilitesini muhafaza edebilmesi bir diğer ifadeyle sistematiğin farklı tarihlerde ve farklı uygulayıcı kişilerce kullanılmasında birbirine yakın sonuçlar alınabilmesi olarak da değerlendirilmiştir.

\section{Teşekkür}

Bu çalışma doktora tezinden özetlenmiş olup çalışmasya İstanbul Üniversitesi BAP birimi tarafindan Proje No: 1224 ile desteklenmiştir.

\section{Kaynaklar}

Baydan, E., Akkaya R., Traş. B., Bilgili A., Tanyıldızı S., Filazi A., Yarsan E. Özdemir. M. (1998): Etlik piliçlerde kullanılan çeşitli veteriner ilaçlarının kalıntıları üzerine pişirme, dondurma ve benzeri 1şlemlerin etkilerinin araştırılması: 1-Sülfonamid grubu baz1 antibakteriyellerin incelenmesi, 2-Kinolon grubu baz1 antibakteriyellerin incelenmesi. TAGEM HS/98/16/02.

Baydan, E,. Özdemir,. M. Kanbur, M. (2001): Kanatlı dokularındaki sülfadiazin kalıntıları üzerine pişirme, dondurma ve benzeri işlemlerin etkileri, Çiftlik Dergisi, 203: 8190.

Bishop, Y.M. (1996): The veterinary formulary: Handbook of Medicines Used in Veterinary 
Practice, $5^{\text {th }}$ ed., Royal Pharmaceutical Society of Great Britain and British Veterinary Association, London, pp.176178.

Bories, G., Brantom, P., Barberà, J.B., Chesson, A., Cocconcelli, P.S., Debski, B., Dierick, N., Franklin, A., Gropp, J., Halle, I., Hogstrand, C., Knecht, J., Leng, L., Haldorsen, A.K.L., Mantovani, A., Mézes, M., Nebbia, C., Rambeck, W., Rychen, G., Wright, A., Wester, P. (2007): Safety of Kokcisan $120 \mathrm{G}$ as a feed additive for chickens for fattening. Updated scientific opinion of the panel on additives and products or substances used in animal feed. European Food Safety Authority. The EFSA Journal, 547: 1-10.

Dehai, X., Grizzle, J.M., Rogers, W.A., Santerre, C.R. (1996): Effect of cooking on residues of ormetoprim and sulfadimethoxine in the muscle of channel catfish. Food

Research

International, 29(3-4): 339-344.

Dubois, M.G., Pierret, D. (2004): Efficient and sensitive detection of residues of nine coccidiostats in egg and muscle by liquid chromatography-electrospray tandem mass spectrometry. Journal of Chromatography B, 813(1-2): 181-189.

Ebrahimezhad, Y. (2005): Effects of 1onophorous drugs, salinomycin and lasalocid, on the performance of broiler chicks and the relations ship of these drugs to suplemantary methionin. Journal of Poultry Science, 4(11): 911-916.

EFSA, (2004): Opinion of the scientific Panel on Additives and Products or Substances used in Animal Feed on a request from the Commission on the re-evaluation of coccidiostat Sacox $120 \circledR$ micro Granulate in accordance with article $9 \mathrm{G}$ of Council Directive 70/524/EEC. The EFSA Journal, 76: $1-49$.

http://www.efsa.europa.eu/en/efsajournal/d oc/76.pdf

EFSA (2004): Opinion of the Scientific Panel on Additives and Products or Substances used in Animal Feed on the reevaluation of coccidiostat Avatec in accordance with article 9G of Council Directive 70/524/EEC. The EFSA Journal, 53: 1-44. http://www.efsa.europa.eu/en/efsajournal/d oc/53.pdf

EFSA (2004): Update of an opinion of the Scientific Panel on Additives and Products or Substances used in Animal Feed on the re-evaluation of coccidiostat Avatec in accordance with article $9 \mathrm{G}$ of council directive 70/524/EEC, The EFSA Journal, 77: 1-45.

http://www.efsa.europa.eu/en/efsajournal/d oc/77.pdf

EFSA (2006): Update of the opinion of the scientific panel on additives and products or substances used in animal feed on a request from the European Commission related to the safety and efficiacy of 'Kokcisan 120G" The EFSA Journal, 378: 1-12. http://www.efsa.europa.eu/en/efsajournal/d oc/378.pdf

12-EFSA, (2007): Cross-contamination of nontarget feedingstuffs by lasalocid authorised for use as a feed additive Scientific opinion of the panel on contaminants in the food chain. European Food Safety Authority, The EFSA Journal, 553: 1-46. http://www.efsa.europa.eu/en/efsajournal/d oc/553.pdf

Elliot, C.T., Kennedy, D.G., McCaughey, W.J. (1998): Methods for the detection of polyether ionophore residues in poultry. Veterinary Science Division, 123: 45-56.

EMEA (1999): Commision Directive 1997/76/EC. Annex. Determination of lasalocid sodium. 23 July 1999.

EMEA (2004): Lasalocid Sodium. Summary Report of the Commitee for Veterinary Medicinal Products. Summary Report. EMEA/MRL/912/04-Final, Oct.2004. http://www.ema.europa.eu/docs/en GB/do cument library/Maximum Residue Limits - Report/2009/11/WC500014596.pdf

Gıda Tarım ve Hayvancılık Bakanlığı (GTHB), Gıda kontrol Genel Müdürlüğü (GKGM) (2007): GTHB Ulusal Kalıntı Kontrol Plan1.

http://www.veterinerx.com/dosyalar/2007 ulusal kalinti_izleme_plani.pdf 
Jordan, F.T.W. (1990): Poultry disease. Bailliere Tindal, Oval road London/England. ISBN 0-7020-1339-0/24-28.

Kennedy, D.G., Hughes, P.J., Blanchflower, W.J. (1998): Ionophore residues in eggs in Northern Ireland: incidence and cause. Food Additives \& Contaminants, 15(5): 535-541.

Kennedy, D.G., Hughes, P.J., Blanchflower, W.J., (1996): The incidens and cause of lasalocide residues in eggs in Northen Ireland. Food Additives \& Contaminants, 13(7): 787-794.

Matabudul, D.K., Lumley, I.D., Points J.S. (2002): The determination of 5 anticoccidial drugs (nicarbazin, lasalocid, monensin, salinomycin and narasin) in animal livers and eggs by liquid chromatography linked with tandem mass spectrometry (LC-MSMS). Analyst. 127(6): 760-768.

McDouglas, L.R., Seibert, B.P. (1998): Residuel activity of veteriner drugs in chickens after withdrwal of medicated feed. Veterinary Parasitology, 74: 91-99.

McEvoy, J.D.G. (2002): Contamination of animal feedingstuffs as cause of residues in food: a review of regulatory aspects, incidence and control. Analytica Chemica Acta, 473: 3-26.

Mortier, L., Daeseleire, E., Peteghem, C.V. (2004): Liquid chromatographic tandem mass spectrometric determination of five coccidiostats in poultry eggs and feed. Journal of Chromatography B, 820: 261270.

Mortier L, Huet, A.C., Charlier, C., Daeseleire, E., Delahaut, P., Van Peteghem, C. (2005): Incidence of residues of nine anticoccidials in eggs. Food Additives \& Contaminants, 22(11): 1120-1125.

Oehme, F.W., Pickrell, J.A. (1999): An analysis of the chronic oral toxicity of polyether ionophore antibiotics in animals. Veterinary and Human Toxicology, 41(4): 251-257.

Parelman, B., Pirak, M., Smith, B. (1993): Effect on the accidental feeding lasalocide sodium to broiler breeder chickens. Veterinary Record, 132(11): 271-273.

Regulation (EC), (2003): European Parliament and the council of 22 September 2003 on additives for use in animal nutrition E.C.No: 1831/2003/E-JC.

Resmi Gazete (2005): GTHB, Canlı Hayvanlar ve Hayvansal Ürünlerde Belirli Maddeler Ile Bunların Kalıntılarının Izlenmesi Için Alınacak Önlemlere Dair Yönetmelik. Resmi Gazete: 19.01.2005, No: 25705.

Resmi Gazete (2007): Gida Tarım ve Hayvancılık Bakanlığı(GTHB). Yem Katk1 ve Premikslerin Üretimi, İthalat1, İhracat1, Satışı ve Kullanımı Hakkında Tebliğde Değişiklik Yapılmasına Dair Tebliğ. Yetki Kanunu: 1734, Yayımlandığ 1 Resmi Gazete: 03.05.2007, say1: 26511, Tebliğ No $2007 / 9$.

Resmi Gazete (2007): Türk G1da Kodeksi Hayvansal Kökenli Gıdalarda Veteriner İlaçları Maksimum Kalıntı Limitleri Tebliğinde değişiklik yapılması hakkında tebliğ. Tebliğ No: 2007/17, Resmi Gazete 09.03.2007, Say1: 26457.

Rokka, M., Eerola, S., Perttila, U., Rossow, L., Venalainen, E., Valkonen. E., Valaja. J., Peltonen, K. (2005): The residue levels of narasin in eggs of laying hens fed with unmedicated and medicated feed. Molecular Nutrition \& Food Research, 49(1):38-42.

Rokka, M., Peltonen, K. (2006): Simultaneus determination of four coccidiostats in eggs and broiler meat: validation of an LCMS/MS method. Food Additives \& Contaminants, 23: 470-478.

Rosen, J. (2001): Efficient and sensitive screening and confirmation of residues of selected polyether ionophore antibiotics in liver and eggs by Liquid chromatographyelectrospray tandem mass spectrometry. Analyst, 126(11): 1990-1995.

Şanll, Y., Akar, F., Bilgili, A.,(1993): Et tipi piliçlerde altlığı 1slatma sendromuna yol açan katılımcı etmenler üzerinde araştırmalar. Uluslararası Tavukçuluk Kongresi, 13-14 May1s 1993, İstanbul Bilimsel Tavukçuluk Derneği Yayınları, s. 376-389. 